\title{
$Z$ delom povezani dejavniki tveganja za samomorilno vedenje, varovalni dejavniki in možnosti preventivnega delovanja
}

Slovenski center za raziskovanje samomora, Inštitut Andrej Marušič, Univerza na Primorskem

\begin{abstract}
Povzetek: Delo je kot pomemben vidik posameznikovega življenja v odraslosti tesno povezano z zdravjem in duševnim zdravjem. Vidiki poklica, dela in zaposlitve lahko predstavljajo dejavnike tveganja za razvoj samomorilnega vedenja ali varovalne dejavnike, ki zmanjšujejo verjetnost le-tega. Namen prispevka je predstaviti poznane dejavnike tveganja za samomorilno vedenje in varovalne dejavnike, povezane $\mathrm{z}$ delom oz. zaposlitvijo, ter možnosti preventivnega delovanja $\mathrm{v}$ tem kontekstu. Pomemben dejavnik tveganja za samomorilno vedenje predstavlja brezposelnost. Povezanost med brezposelnostjo in samomorilnostjo je kompleksna in zanjo obstajata dve razlagi: (i) predhodna ranljivost naj bi vodila tako v brezposelnost kot samomorilno vedenje, (ii) hkrati pa naj bi bila povezanost do neke mere tudi vzročne narave. Obravnavana tematika je zelo pomembna $\mathrm{v}$ času ekonomske recesije, ko je stopnja brezposelnosti visoka in prihaja do neugodnih sprememb $\mathrm{v}$ pogojih dela. S samomorilnim vedenjem so povezani tudi različni psihosocialni in drugi pogoji dela. Učinkovite preventivne dejavnosti vključujejo pristope na več ravneh: aktivno politiko reševanja ekonomske krize in izboljšanja razmer na trgu dela, ustvarjanje in vzdrževanje spodbudnih delovnih pogojev, ozaveščanje in krepitev duševnega zdravja zaposlenih, izobraževanje vratarjev sistema ter preprečevanje dostopa do sredstev za samomor pri poklicih z dostopom do njih. Zaradi kompleksnosti samomorilnega vedenja se na tem področju kažejo potrebe po nadaljnjih raziskavah, ki bi pripomogle k boljšemu razumevanju specifičnih dejavnikov tveganja in zlasti varovalnih dejavnikov v ogroženih skupinah.
\end{abstract}

Ključne besede: samomor, delo, zaposlitev, dejavniki tveganja, preventiva

\section{Work-related risk factors for suicidal behaviour, protective factors and possibilities for prevention}

\author{
Tina Podlogar \\ Slovene center for suicide research, Andrej Marušič Institute, University of Primorska, Slovenia
}

\begin{abstract}
Work is an important part of adult life. As such it is closely connected to health and mental health. Aspects of occupation, work and employment can represent risk factors for suicidal behaviour or protective factors against it. Aim of this article is to present the known work-related risk factors for suicidal behaviour, protective factors and possibilities for preventive activities in this context. An important risk factor for suicidal behaviour is unemployment. Connection between unemployment and suicidality is complex and can be explained in two ways: (i) underlying vulnerability leads to both unemployment and suicidal behaviour, while (ii) the connection is also thought be causal to some extent. The addressed topic is very important in the period of economic recession, when unemployment rates are high and adverse changes in terms of working conditions can occur. Different psycho-social and other working conditions are also connected to suicidal behaviour. Efficient preventive activities include approaches on multiple levels: active politics of solving economic crisis and improving the labour market conditions, creating and maintaining stimulating working conditions, raising awareness and mental health promotion among the employees, gatekeeper training, and restriction of means for suicide in occupations with access to them. Due to complexity of suicidal behaviour there is a need for further research, which would contribute to better understanding of specific risk factors and especially protective factors in vulnerable groups.
\end{abstract}

Keywords: suicide, work, employment, risk factors, prevention

\footnotetext{
"Naslov/Address: Tina Podlogar, Slovenski center za raziskovanje samomora, Inštitut Andrej Marušič, Univerza na Primorskem, Muzejski trg 2, 6000 Koper, e-pošta: tina.podlogar@upr.si

Članek je licenciran pod pogoji Creative Commons Attribution 4.0 International licence. (CC-BY licenca).

The article is licensed under a Creative Commons Attribution 4.0 International License (CC-BY license).
} 
Slovenija se po številu samomorov uvršča med najbolj ogrožene države na svetu. V zadnjih desetletjih smo sicer beležili spodbuden trend upadanja števila samomorov. Količnik samomora, tj. število samomorov na 100.000 prebivalcev na leto, je upadel $\mathrm{z}$ okoli $30 \mathrm{v}$ osemdesetih in devetdesetih letih prejšnjega stoletja letih na 21 v letu 2007, nato je nekaj let ostal približno konstanten in znašal 20-21 (WHO, 2014), v letu 2014 pa smo v Sloveniji zabeležili ponovni upad količnika samomora, saj je ta znašal 18,8 (NIJZ, 2015). Videti je, da je ustalitev količnika samomora sovpadala $\mathrm{z}$ obdobjem ekonomske recesije, vendar bi bile za trdnejše zaključke potrebne natančnejše analize, ki bi upoštevale podatke daljših časovnih obdobij in različne druge dejavnike; zato ne moremo govoriti o vzročnoposledični zvezi.

Samomor je kompleksen fenomen, na katerega vplivajo številni med seboj prepletajoči se dejavniki; pomembni so tako genetski kot okoljski dejavniki, poleg tega pa tudi interakcija med obojimi (Mann, Waternaux, Haas in Malone, 1999). Zaradi kompleksnosti človeške duševnosti in samomorilnega procesa navadno ne govorimo o konkretnih, določenih vzrokih, zaradi katerih bi se posameznik odločil za samomor, temveč o dejavnikih tveganja, ki povečujejo verjetnost za razvoj samomorilnega vedenja, in varovalnih dejavnikih, ki to verjetnost zmanjšujejo. Dejavnike tveganja in varovalne dejavnike prepoznavamo $\mathrm{v}$ bioloških predispozicijah posameznika, njegovem psihosocialnem razvoju ter medsebojnem sovplivanju teh tesno prepletenih in soodvisnih področij.

Dejavniki tveganja za samomorilno vedenje so $\mathrm{v}$ Sloveniji podobni kot drugje po svetu. Več samomorov beležimo pri moških (razmerje med samomori moških in žensk znaša približno $3,4: 1$ ), starejših, ločenih, ovdovelih in samskih, pri osebah z duševnimi boleznimi, tveganim in škodljivim pitjem alkohola, preteklimi poskusi samomora in zgodovino samomorilnega vedenja v družini; poleg tega pa tudi pri brezposelnih in posameznikih $\mathrm{z}$ nižjo izobrazbo (O’Connor in Nock, 2014; Roškar, 2009). V primerjavi s številnimi študijami o dejavnikih tveganja za samomor so varovalni dejavniki, ki varujejo pred samomorilnim vedenjem, slabše raziskani (O'Connor in Nock, 2014; O’Connor, 2011; Rihmer, 2011). Znano pa je, da imajo pomembno varovalno vlogo dejavniki kot npr. dobra socialna mreža, podpora družine, obdobje po rojstvu otroka, večje število otrok, močna verska prepričanja (Rihmer, 2011), zakonska zveza (Windfuhr in Kapur, 2011) ter osebnostne in kognitivne lastnosti posameznika, kot so optimizem, psihološka odpornost, zmožnost soočanja s težavami in reševanja problemov, osebni cilji in razlogi za življenje (O’Connor in Nock, 2014) itd. Varovalni dejavniki so odvisni tudi od kulturnega in socialnega konteksta ter značilnosti ciljne populacije.

Delo oz. zaposlitev predstavlja pomemben vidik posameznikovega življenja in identitete $\mathrm{v}$ odraslosti. Dejavniki, povezani z zaposlitvijo in delovnim okoljem, so tako tesno povezani $\mathrm{z}$ različnimi vidiki zdravja in duševnega zdravja. $\mathrm{V}$ tem kontekstu predstavljajo tudi pomembne dejavnike tveganja za samomorilno vedenje ter varovalne dejavnike (Makinen in Wasserman, 2009). Pričujoči prispevek je namenjen pregledu sodobne znanstvene literature in spoznanj o najpomembnejših vidikih dela in zaposlitve, povezanih s samomorilnim vedenjem. Poznavanje oz. razumevanje z delom povezanih dejavnikov tveganja za samomor in varovalnih dejavnikov, ki ščitijo pred samomorilnim vedenjem, je pomembno $\mathrm{z}$ vidika razumevanja trendov spreminjanja količnikov samomora $\mathrm{v}$ času in razlik med posameznimi skupinami prebivalstva, boljšega prepoznavanja samomorilno ogroženih posameznikov in razumevanja njihovega doživljanja ter načrtovanja in izvedbe preventivnih aktivnosti za krepitev duševnega zdravja in preprečevanja samomorilnega vedenja. Obravnavana tema je še zlasti pomembna $\mathrm{V}$ obdobju ekonomske recesije, ko se $\mathrm{Z}$ brezposelnostjo, slabšimi pogoji pri delu in/ali drugimi posledicami gospodarske krize neposredno ali posredno naenkrat sooča večje število ljudi.

\section{Povezanost brezposelnosti s samomorilno ogroženostjo}

Ker ima zaposlitev v posameznikovem življenju tako pomembno vlogo (od finančne varnosti do zadovoljevanja psiholoških potreb po socialnih stikih, samoaktualizaciji, osebnostni rasti itd.), je povezanost brezposelnosti $\mathrm{z}$ neugodnimi izidi pričakovana. Številne raziskave kažejo, da je brezposelnost eden od pomembnih dejavnikov tveganja za samomorilnost (npr. Agerbo, Gunnell, Bonde, Mortensen in Nordentoft, 2007; Almasi idr., 2009; Crump, Sundquist, Sundquist in Winkleby, 2014; Goldman-Mellor, Saxton in Catalano, 2010; Korošec Jagodič, Rokavec, Agius in Pregelj, 2013; Legleye, Beck, Peretti-Watel, Chau in Firdion, 2010; Milner, Page in LaMontagne, 2013; Platt, 2011; Schneider idr., 2011; WHO, 2006). Pri tem naj bi bilo tveganje za samomor med brezposelnimi posamezniki v povprečju dva do trikrat večje kot pri zaposlenih osebah (Agerbo, 2005; Blakely, Collings in Atkinson, 2003).

Tudi rezultati študije trendov količnikov samomora v 26 evropskih državah v letih 1980-2008 (Yur'yev, Värnik, Värnik, Sisask in Leppik, 2012) kažejo na pozitivno povezanost med količnikom samomora in brezposelnostjo v večini držav. V nekaterih državah, med katerimi je bila tudi Slovenija, avtorji takšne povezanosti niso odkrili, kar bi lahko bilo po njihovem mnenju povezano s pomembnimi spremembami na trgu dela v obravnavanem obdobju (npr. socio-ekonomske spremembe, vezane na razpad Sovjetske zveze v vzhodno-evropskih državah, fluktuacija na trgu dela zaradi finančne krize $\mathrm{v}$ skandinavskih državah). Opozarjajo pa, da to ni celostna razlaga, ter da bi bilo potrebno za jasnejše zaključke analizirati dolgotrajnejše trende z natančnejšimi podatki (Yur'yev idr., 2012). Predvsem bi bilo smiselno v analizo dogajanja v Sloveniji vključiti podatke zadnjih let, torej obdobja recesije. Poleg tega so za Slovenijo značilne velike razlike med regijami (tako ekonomsko-socialne, kot tudi razlike v količnikih samomora, ki so najvišji v severovzhodnih regijah, najnižji 
pa na jugozahodu Slovenije). Analiza podatkov iz let 2000 do 2009 kaže, da je stopnja brezposelnosti v posameznih slovenskih statističnih regijah pozitivno povezana $\mathrm{s}$ količniki samomora (Korošec Jagodič idr., 2013).

Raziskave, ki natančneje preučujejo dejavnike tveganja za samomorilno vedenje med brezposelnimi, pripomorejo $\mathrm{k}$ boljšemu prepoznavanju samomorilne ogroženosti med njimi glede na različne druge dejavnike in okoliščine. Ena od pomembnih okoliščin, povezanih z razvojem samomorilnega procesa, je denimo to, koliko časa je posameznik brezposeln. Nekatere raziskave kažejo, da je s samomorilnimi mislimi povezana izguba službe v zadnjih 12 mesecih (Vanderoost, Van Der Wielen, Van Nunen in Van Hal, 2013). Izguba zaposlitve lahko povzroči zmanjšanje občutka finančne varnosti in pomembno spremembo v posameznikovem življenju, oseba pa jo lahko doživlja kot sporočilo o lastnem neuspehu in nekompetentnosti, pri čemer se pojavijo občutki sramu ter negativne misli in čustva, vezana na izgubo službe. Drugi avtorji pa ugotavljajo, da je s povečanim tveganjem za samomorilno vedenje povezan daljši čas brezposelnosti (Classen in Dunn, 2012), kar naj bi bilo povezano $\mathrm{z}$ naraščanjem občutka brezupa $\mathrm{z}$ daljšanjem obdobja brezposelnosti (Milner, Page idr., 2013). Videti je torej, da sta tako sama izguba službe kot tudi daljše trajanje brezposelnosti dejavnika tveganja. Za prepoznavanje samomorilne ogroženosti pri posamezniku pa je pomembno vprašanje, v kakšnem kontekstu lahko vsak od njiju pomembno vpliva na posameznika (npr. v kombinaciji z drugimi dejavniki tveganja ter ob pomanjkanju varovalnih dejavnikov).

Nekateri avtorji glede povezanosti brezposelnosti s samomorilnostjo ugotavljajo razlike med spoloma, vendar rezultati študij med seboj niso skladni (Blakely idr., 2003). $\mathrm{V}$ nekaterih raziskavah se močnejša povezanost kaže pri moških (Barr, Taylor-Robinson, Scott-Samuel, McKee in Stuckler, 2012; Legleye idr., 2010; Norström in Grönqvist, 2015; Ying in Chang, 2009), v drugih pa pri ženskah (Kposowa, 2001; Milner, Morrell in LaMontagne, 2014). Pompili idr. (2014) so $\mathrm{v}$ študiji $\mathrm{z}$ metodo psihološke avtopsije med seboj primerjali brezposelne in zaposlene žrtve samomora. Ugotovili so, da so bili brezposelni v primerjavi z zaposlenimi v povprečju nekoliko mlajši, manj pogosto poročeni, pogosteje so uporabljali nedovoljene droge ali predpisana zdravila, njihova socialna opora je bila pogosteje slaba, pogosteje so imeli tudi finančne težave ter osebnostne motnje. V primerjavi brezposelnih žrtev samomora s kontrolno skupino brezposelnih oseb brez zgodovine samomorilnega vedenja pa so kot dejavnike tveganja identificirali moški spol, slabo socialno oporo, večje število stresnih dogodkov v zadnjih 12 mesecih ter diagnozo mejne osebnostne motnje, medtem ko je bila pretekla hospitalizacija na psihiatričnem oddelku pogostejša v kontrolni skupini (Pompili idr., 2014).

Glede povezanosti brezposelnosti $\mathrm{s}$ povišanim tveganjem za samomorilno vedenje obstajata dve razlagi (Corcoran in Arensman, 2010; Platt, 2011): (i) pri brezposelnih posameznikih lahko obstaja predhodna ranljivost, npr. duševna bolezen, ki vodi v brezposelnost (ali jo ohranja), kot tudi v samomorilno vedenje; (ii) med brezposelnostjo in samomorilnim vedenjem obstaja vzročna povezanost, saj brezposelnost prek dejavnikov, kot so povišana stopnja psihološkega stresa, finančne skrbi/težave, negativen vpliv na samopodobo, umik iz socialnega življenja, zloraba psihoaktivnih substanc, duševna bolezen itd. (Beautrais, Joyce in Mulder, 1998), povzroča ranljivost za samomorilno vedenje. Študije $s$ tega področja ne dajejo enoznačnih rezultatov, kar kaže na to, da je povezanost brezposelnosti s samomorilnim vedenjem kompleksna. Vzročne narave naj bi bila predvsem kratkoročno, torej $\mathrm{v}$ določenem obdobju po izgubi zaposlitve (Makinen, 1999). Po drugi strani pa ne gre izključevati ali minimalizirati pomena predhodne ranljivosti, tj. ne-vzročne povezanosti med brezposelnostjo in samomorilnim vedenjem (Platt, 2011). V skladu s teoretičnim okvirjem, ki samomorilno vedenje razlaga skozi prepletanje in sovplivanje genetskih in okoljskih dejavnikov (Mann idr., 1999), lahko pravzaprav sklepamo, da sta obe razlagi ustrezni, $v$ različnih okoliščinah pa imata morda lahko različno velik pomen. Kljub pomanjkanju enoznačnega odgovora na ta vprašanja ponujajo raziskave vpogled v nekatere dejavnike, kar omogoča načrtovanje in izvedbo intervencij za preprečevanje samomorilnega vedenja.

\section{Samomorilno vedenje $\mathbf{v}$ času ekonomske recesije}

V obdobju ekonomske recesije je obravnavana problematika zelo pomembna, saj se z brezposelnostjo naenkrat sooča večje število ljudi kot v obdobju gospodarske rasti. Poleg tega je potrebno upoštevati, da recesija na različne načine vpliva tudi na posameznike, ki sami ne izgubijo službe oz. niso brezposelni. Lahko se soočajo s spremenjenimi pogoji na lastnem delovnem mestu (npr. nižja plača in/ali manjši občutek varnosti zaposlitve, ki lahko vodi v povišan stres in povečano količino dela, nezadovoljstvo pri delu, preobremenjenost in izgorelost), z izgubo zaposlitve pri družinskih članih (kar lahko prav tako povzroči izgubo občutka finančne varnosti in druge težave v družini) ter podobnimi stresnimi situacijami.

$\mathrm{V}$ kontekstu razumevanja vpliva ekonomske recesije na pojavnost samomorilnega vedenja se zastavljajo vprašanja glede splošnih trendov samomorilnega vedenja v različnih časovnih obdobjih gospodarske rasti ali recesije, in glede tega, ali izguba zaposlitve v času recesije na posameznika vpliva drugače kot $\mathrm{v}$ času ekonomske stagnacije ali rasti. V študiji trendov spreminjanja stopnje brezposelnosti in njene povezanosti s količniki samomora v 26 državah Evropske Unije med leti 1970 in 2007 se je izkazalo, da je vsak $1 \%$ povečanja brezposelnosti v povprečju povezan z 0,79 -odstotnim povečanjem števila samomorov pri posameznikih, mlajših od 65 let (Stuckler, Basu, Suhrcke, Coutts in McKee, 2009). Ob tem se je pozitivna povezanost stopnje brezposelnosti s količnikom samomora pokazala za močnejšo $\mathrm{v}$ državah $\mathrm{z}$ nižjo 
stopnjo brezposelnosti pred recesijo, manjša pa je bila $\mathrm{v}$ državah, v katerih je bila brezposelnost visoka že prej. Prebivalci držav z nizko osnovno stopnjo brezposelnosti morda ob negativnih ekonomskih spremembah doživljajo večjo stopnjo psihološkega stresa, po drugi strani pa lahko predstavlja izguba službe v državah z višjo osnovno stopnjo brezposelnosti manj stigmatizirajoč dogodek (Chang, Stuckler, Yip in Gunnell, 2013). Podatki torej kažejo na to, da je večja stopnja brezposelnosti v družbi povezana $\mathrm{z}$ višjim skupnim količnikom samomora. Recesija se tako na splošno kaže kot pomemben dejavnik tveganja za samomorilnost $\mathrm{v}$ populaciji ne glede na zaposlitveni status (npr. Barr idr., 2012; Laanani, Ghosn, Jougla in Rey, 2014; Norström in Grönqvist, 2015; Yip in Caine, 2011). V obdobju recesije bi lahko na porast števila samomorov med brezposelnimi vplivala npr. čustva brezupa, ki se morda pojavljajo ob izgubi službe in/ali neuspešnem iskanju zaposlitve, v okoliščinah, v katerih so možnosti za uspešno iskanje službe majhne (Norström in Grönqvist, 2015). Povišanje količnika samomora v skupini zaposlenih $\mathrm{v}$ času recesije pa lahko razlagamo npr. $\mathrm{z}$ vplivom znižanja prihodka in neželenih sprememb glede drugih delovnih pogojev in okoliščin, npr. večje količine stresa zaradi manjše varnosti zaposlitve itd. (Milner, Morrell, idr., 2014).

Vendar raziskave, ki temeljijo na povezanosti stopnje brezposelnosti in skupnega količnika samomora v družbi, ne omogočajo vpogleda $\mathrm{v}$ trende spreminjanja količnikov samomora posebej v skupinah zaposlenih in brezposelnih. Zato je pomembno opozoriti tudi na študije, ki natančneje preučujejo samomorilno vedenje v posameznih skupinah prebivalstva. S spreminjanjem razmer $\mathrm{v}$ gospodarstvu je namreč povezana tudi sama napovedna vrednost brezposelnosti za samomorilno vedenje. V pregledni študiji, analizi napovedne vrednosti socio-demografskih dejavnikov tveganja za samomorilno vedenje na podlagi raziskav, objavljenih med leti 1950 in 2006, se je izkazalo, da je v primeru visoke stopnje brezposelnosti povezanost med brezposelnostjo in količnikom samomora šibkejša kot v primeru nizke stopnje brezposelnosti (Crawford, Kuforiji in Ghosh, 2010). Brezposelnost je torej v času ekonomske krize manj pomemben napovedni dejavnik za samomorilno vedenje (Crawford idr., 2010; Yip in Caine, 2011). Večja napovedna vrednost brezposelnosti za količnik samomora v času nizke stopnje brezposelnosti je skladna $\mathrm{z}$ obema omenjenima razlagama povezanosti med brezposelnostjo in samomorilnim vedenjem. V takšnih gospodarskih razmerah so morda predvsem najbolj ranljivi posamezniki brez zaposlitve; razlika $\mathrm{v}$ samomorilnosti med zaposlenimi in brezposelnimi se $\mathrm{v}$ tem primeru maksimizira. Obenem je v času nizke brezposelnosti lahko učinek le-te (v smislu negativnega vpliva na samopodobo, vpliva na socialno življenje, stigmatiziranost itd.) še toliko bolj poudarjen (Corcoran in Arensman, 2010). V času ekonomske recesije pa je po drugi strani lahko izguba službe za posameznika manj stigmatizirajoč dogodek, saj se podobno dogaja tudi številnim drugim članom družbe (Norström in Grönqvist, 2015). V takšnih okoliščinah morda najbolj ranljivi posamezniki ne predstavljajo več večine v skupini brezposelnih in tako postane povezanost med brezposelnostjo in samomorilnim količnikom šibkejša.

\section{Dejavniki tveganja za samomor, povezani z značilnostmi dela}

Glede na to, da predstavlja brezposelnost pomemben dejavnik tveganja za samomor (npr. Agerbo idr., 2007; Almasi idr., 2009; Crump idr., 2014; Goldman-Mellor idr., 2010; Korošec Jagodič idr., 2013; Legleye idr., 2010; Milner, Page idr., 2013; Platt, 2011; Schneider idr., 2011; WHO, 2006), lahko zaposlitev samo po sebi smatramo za varovalni dejavnik, ki ščiti pred samomorilnim vedenjem. Kljub temu pa ne gre spregledati dejstva, da je večina odraslih ljudi, ki naredijo samomor, v delovnem razmerju. Na njihovo ravnanje vplivajo številni dejavniki, vendar lahko glede na pomen dela $\mathrm{v}$ posameznikovem življenju (delovno aktivni posamezniki preživijo v službi razmeroma velik delež časa, pri čemer jim lahko delovno okolje predstavlja vir zadovoljujočih medosebnih odnosov, pozitivnih podkrepitev in priložnosti za osebnostno rast ter krepitev samopodobe - ali pa v primeru neugodnih pogojev, nasprotno, predvsem vir številnih obremenitev, neobvladljivega stresa, težav $\mathrm{v}$ socialnih odnosih, mobinga in podobno) predvidevamo, da tudi $\mathrm{z}$ delom povezani dejavniki pomembno vplivajo na pojavljanje samomorilnih misli in razvoj samomorilnega procesa.

V zadnjih letih se raziskovalci samomorilnega vedenja začenjajo ukvarjati z vprašanjem, kateri so tisti vidiki dela, ki vplivajo na povišanje tveganja za samomorilno vedenje. Še vedno pa je tovrstnih študij, kot opozarjajo Schneider idr. (2011), relativno malo, glede na znano dejstvo, da določeni vidiki dela in $\mathrm{z}$ delom povezan stres povzročajo pojav izgorelosti, simptomov depresije in tveganja za kasnejše psihiatrične diagnoze. Svetovna zdravstvena organizacija poudarja, da je s samomorilnostjo povezana dolgotrajna izpostavljenost stresu na delovnem mestu, katerega opredeljuje kot neskladje med zahtevami zaposlitve oz. delovnega okolja ter zmožnostmi, dosegljivimi viri ter potrebami zaposlenega (WHO, 2006). Konkretneje, raziskave $\mathrm{s}$ tega področja kažejo, da so $\mathrm{s}$ povišanim tveganjem za samomorilno vedenje povezani neugodni psihosocialni delovni pogoji, npr. slaba socialna podpora (Amagasa, Nakayama in Takahashi, 2005; Ostry idr., 2007), visoka stopnja doživljanja stresa na delovnem mestu (Feskanich idr., 2002) ter nizka stopnja zaznane kontrole pri delu (Tsutsumi idr., 2007). Tudi v študiji zdravnikov se je izkazalo, da je samomorilna ideacija povezana s pomanjkanjem nadzora nad pogoji dela, poleg tega pa tudi s konfliktom vlog na delovnem mestu (Fridner idr., 2011). Ugodne delovne razmere, kot podpora na delovnem mestu $\mathrm{v}$ primeru težav in zaupni pogovori o delovnih izkušnjah, pa so se izkazale za varovalne dejavnike (Fridner idr., 2011). Schneider idr. 
(2011) podobno ugotavljajo, da so s povišanim tveganjem za samomorilno vedenje povezani neugodni psihosocialni delovni pogoji, npr. monotono delo, visoka/povečana odgovornost, izrazita psihološka obremenitev zaradi kontakta s strankami, in sicer neodvisno od psihiatrične diagnoze. S povečanim tveganjem za samomorilnost je povezana tudi nizka stopnja formalne in strokovne izobrazbe ter pogosto menjanje služb, npr. zamenjava treh ali več služb v zadnjih petih letih (Schneider idr., 2011). Avtorji poleg tega ugotavljajo povezanost samomorilnega vedenja $\mathrm{z}$ dolgimi delovniki in težkim delom (Amagasa idr., 2005) ter skrbmi glede stabilnosti zaposlitve v prihodnosti (Almasi idr., 2009).

\section{Samomorilna ogroženost v različnih poklicih in poklicnih skupinah}

Avtorji nedavnega sistematičnega pregleda člankov in meta-analize (večinoma študij iz držav $z$ visokim prihodkom) so predpostavljali, da je tveganje za samomorilno vedenje povezano $\mathrm{z}$ nivojem spretnosti, potrebnih za opravljanje različnih poklicev(Milner, Spittal, Pirkis in LaMontagne, 2013). Za klasifikacijo poklicev so uporabili mednarodno standardno klasifikacijo poklicev - ISCO sistem, v katerem so poklici razvrščeni glede na različne nivoje spretnosti. Pri nekaterih poklicnih skupinah obstaja povišana ogroženost za samomorilno vedenje: najbolj so najbolj ogroženi delavci, čistilci in zaposleni v poklicih za preprosta dela (ISCO kategorija 9), sledijo pa jim upravljavci strojev in člani posadke na ladjah (ISCO kategorija 8). Z omenjenimi poklicnimi skupinami je bilo narejenih relativno malo raziskav, kar je presenetljivo glede na to, da gre za najbolj ogrožene skupine zaposlenih. Povišano tveganje za samomorilno vedenje je opaziti tudi pri kmetih in agrokulturnih delavcih (ISCO kategorija 6), izvajalcih storitev, npr. policistih (ISCO kategorija 5), ter izvajalcih obrtniških storitev, npr. gradbincih, električarjih (ISCO kategorija 7), medtem ko je količnik samomora najnižji med managerji (ISCO kategorija 1) in uradniškimi delavci (ISCO kategorija 4). Rezultati torej potrjujejo obstoj razlik med količniki samomora pri zaposlenih v poklicih, za katere so potrebni različni nivoji spretnosti, pri čemer so najbolj ogroženi zaposleni $\mathrm{v}$ poklicih z najnižjimi nivoji potrebnih spretnosti (Milner, Spittal idr., 2013).

Preučevanje ogroženosti za samomorilno vedenje znotraj različnih poklicev skozi čas kaže, da se stopnja ogroženosti posameznih poklicnih skupin spreminja (Roberts, Jaremin in Lloyd, 2013). Roberts idr. (2013) so raziskali ogroženost posameznih poklicev v Angliji in Walesu v dveh časovnih obdobjih: v letih 1979-1980 in 1982-1983 (v tem prvem časovnem obdobju je bila $\mathrm{V}$ analizo vključena tudi Škotska) ter v letih 2001-2005. $\mathrm{V}$ obeh časovnih obdobjih skupaj so identificirali 55 poklicev $\mathrm{z}$ visokim tveganjem (tj. $>20$ na 100.000 zaposlenih na leto), pri čemer so količniki samomora pri 14 poklicih $\mathrm{v}$ času med prvim in drugim opazovanim obdobjem upadli (npr. hotelski uslužbenci, veterinarji, farmacevti, zdravniki, zobozdravniki, frizerji, fotografi, pisatelji, novinarji, kmetje itd.); pri petih poklicih pa so količniki samomora narasli (rudarji premoga, delavci v gradbenih poklicih, slikopleskarji, vozniki viličarjev in tesarji). Opaziti je torej trend zniževanja samomorilne ogroženosti pri pretežno strokovnih poklicih, pri katerih je bilo v preteklosti tveganje za samomorilno vedenje povišano predvsem zaradi poklicnega dostopa do različnih metod za samomor. Po drugi strani pa se je samomorilna ogroženost povišala med poklici, pri katerih se opravlja fizično delo. Do pomembne spremembe je prišlo tudi glede povezanosti socio-ekonomskih dejavnikov $\mathrm{s}$ samomorilnostjo; ti dejavniki so v prvem opazovanem obdobju pojasnjevali $11,4 \%$ variabilnosti v količnikih samomora, v letih 2001-2005 pa kar 20,7 \% (Roberts idr., 2013).

Različne raziskave dajejo le delno konsistentne rezultate o samomorilni ogroženosti pri različnih poklicih, kar lahko pripišemo številnim vzrokom, npr. razliki v ogroženosti posameznih poklicev $\mathrm{v}$ različnih časovnih obdobjih in $\mathrm{v}$ različnih kulturnih okoljih, majhnemu vplivu značilnosti posameznih poklicev na tveganje za samomorilnost, pa tudi razlikam med spoloma. Avtorji so npr. odkrili zanimiv vzorec povezanosti samomorilne ogroženosti zaposlenih žensk $\mathrm{s}$ spolno strukturo zaposlenih v njihovih poklicih; izkazalo se je namreč, da so ženske, zaposlene v prevladujoče moških poklicih, bolj ogrožene za samomorilno vedenje od žensk, zaposlenih v prevladujoče ženskih poklicih. Ugotovitev bi lahko pomenila, da doživljajo zaposleni v poklicih, v katerih prevladuje nasprotni spol, povišano stopnjo stresa pri delu (Agerbo idr., 2007). Na razlike med rezultati pa verjetno vplivajo tudi razlike $\mathrm{v}$ kvaliteti pridobljenih podatkov v posameznih študijah in uporabljenih raziskovalnih metodah, vključno s nadziranjem različnih sovplivajočih spremenljivk, kot so npr. socio-ekonomski in demografski dejavniki. Zanimivi so rezultati študije, v kateri s poklicem povezana samomorilna ogroženost ob nadzoru prihodka ni bila statistično značilna pri večini obravnavanih poklicev; izjemi pa sta bila poklica zdravnikov in medicinskih sester (Agerbo idr., 2007). Videti je, da je z izjemo »medicinskih« poklicev samomorilna ogroženost v veliki meri povezana $\mathrm{s}$ prihodkom, s tem pa tudi s socialno-ekonomskim statusom, kar je skladno $\mathrm{z}$ ugotovitvami predhodno omenjene britanske študije (Roberts idr., 2013).

Povišano tveganje za samomorilno vedenje pri medicinskih poklicih, tj. zdravnikih, medicinskih sestrah, zobozdravnikih, farmacevtih, veterinarjih ter kirurgih, so sicer ugotovile številne raziskave (Hawton, Agerbo, Simkin, Platt in Mellanby, 2011; Lindfors, Meretoja, Luukkonen, Elovainio in Leino, 2009; Petersen in Burnett, 2008; Platt, Hawton, Simkin in Mellanby, 2012; Schernhammer in Colditz, 2004; Skegg, Firth, Gray in Cox, 2010; Wolfersdorf, 2007), a njihovi rezultati niso povsem konsistentni (Hawton idr., 2011), poleg tega se ogroženost spreminja skozi različna časovna obdobja (Roberts idr., 2013; Rosta in Aasland, 2013). Nekateri avtorji ugotavljajo 
povišano tveganje za samomor znotraj medicinskih poklicev predvsem pri ženskah (Braquehais idr., 2014; Kolves in De Leo, 2013; Platt idr., 2012; Wolfersdorf, 2007), drugi pa so odkrili razlike glede na starost zdravnikov, pri čemer količnik samomora s starostjo raste predvsem pri moških zdravnikih, pri pa ženskah manj (Petersen in Burnett, 2008). Meta-analiza je pokazala zmerno povečano tveganje za samomor med moškimi zdravniki in visoko povečanje tveganja med zdravnicami, vendar avtorji zaradi možnosti pristranskosti objavljenih člankov opozarjajo na potrebo po obsežnejših študijah (Schernhammer in Colditz, 2004). K visoki ogroženosti teh poklicnih skupin med drugim prispevata dostop do nekaterih metod za samomor in znanje o možnih metodah (Skegg idr., 2010), poleg tega pa se pogosto omenjajo npr. poklicne težave, stres in izgorelost (Platt idr., 2012) ter obremenjenost zaradi dežuranja (Lindfors idr., 2009). Avtorji opozarjajo tudi na pomen duševnih bolezni in njihovega neadekvatnega zdravljenja $\mathrm{v}$ povezavi $\mathrm{s}$ stresom na delovnem mestu (Gold, Sen in Schwenk, 2013) ter vlogo medosebnih odnosov (Lindfors idr., 2009). K večjemu tveganju za samomor naj bi prispevale tudi boleče izkušnje, ki so jim zdravstveni delavci priča pri svojem delu, saj vplivajo na izgubo strahu pred bolečino in resnim samomorilnim vedenjem (Fink-Miller, 2015; Van Orden idr., 2010).

\section{Možnosti preventivnega delovanja}

Preventivni ukrepi za preprečevanje samomorilnega vedenja izhajajo iz spoznanj o dejavnikih tveganja in varovalnih dejavnikih. Na podlagi sistematičnega pregleda literature in meta-analiz študij, ki se ukvarjajo s preventivo samomorilnega vedenja, so avtorji (Mann, Haas, Mehlum in Phillips, 2005; van der Feltz-Cornelis idr., 2011) intervencije za preprečevanje samomora razdelili $\mathrm{v}$ štiri skupine, in sicer: (i) delo $\mathrm{z}$ mediji in odgovorno poročanje o samomoru, ozaveščanje splošne javnosti; (ii) implementacija preventivnih aktivnosti $\mathrm{v}$ lokalnih skupnostih, delo z ogroženimi skupinami; (iii) izobraževanje strokovnjakov - t. i. vratarjev sistema; ter (iv) omejevanje dostopa do sredstev za samomor. Vsi intervencije niso enako učinkovite $\mathrm{v}$ vseh kontekstih, obenem pa avtorji poudarjajo, da je večnivojski pristop najbolj ustrezen način preprečevanja samomora. Pomembno vlogo bi lahko med drugim imela ravno integracija različnih preventivnih ukrepov (Mishara in Martin, 2012), a bi bilo vprašanje interakcijskih učinkov sočasneizvedberazličnihaktivnostipotrebnošenatančneje raziskati (van der Feltz-Cornelis idr., 2011). Medtem ko prva skupina intervencij poteka na ravni družbe in zajema komunikacijo s širšo javnostjo, se izvedba intervencij na ostalih treh ravneh osredotoča na specifične ciljne skupine in jih lahko prepoznamo znotraj aktivnosti preprečevanja samomora v kontekstu delovnega okolja.

Pomemben vidik preprečevanja samomorilnega vedenja so tudi različne aktivnosti za izboljšanje gospodarstva na ravni sistema. Ko se npr. v času ekonomske krize z brezposelnostjo in/ali bolj neugodnimi ter negotovimi pogoji na delovnem mestu sooča vse večji delež prebivalstva, ima poleg splošnega ozaveščanja javnosti in odgovornega poročanja o samomoru pomembno preventivno vlogo aktivna politika, usmerjena $\mathrm{v}$ reševanje krize in izboljšanje razmer na trgu dela. Investiranje v trg dela namreč zniža učinek naraščanja brezposelnosti na poviševanje količnika samomora ( Haw, Hawton, Gunnell in Platt, 2015; Stuckler idr., 2009). Aktivnosti za reševanje krize dajejo ljudem občutek, da je neugodno situacijo možno obrniti na bolje in tako preventivno delujejo na pojavljanje čustev nemoči, brezupa in brezizhodnosti oz. ujetosti v situaciji. Ta čustva predstavljajo pomemben dejavnik tveganja za samomorilnost (Williams in Pollock, 2001) in bi se verjetno pojavljala v večji meri, če bi ljudje menili, da se s težavami na trgu dela nihče ne ukvarja, saj bi jim to sporočalo, da je situacija brezupna. Trud vlade, da se obdrži čim več obstoječih delovnih mest, in pomoč posameznikom, ki so izgubili službo, da se lažje soočijo z negativnimi vplivi brezposelnosti ter hitreje najdejo drugo zaposlitev, sta izredno pomembna (Stuckler idr., 2009). Študije potrjujejo, da uspešna ponovna zaposlitev pomembno zniža ali celo izniči tveganja, ki jih za duševno zdravje predstavlja izguba službe (Chang idr., 2013).

$\mathrm{V}$ skladu s preventivnim delovanjem $\mathrm{v}$ skupinah s specifičnimi potrebami so pomembni ukrepi, ki naslavljajo konkretne, $\mathrm{z}$ delom povezane dejavnike tveganja za samomorilno vedenje, s pomočjo katerih delodajalec ustvarja boljše pogoje dela, ki pripomorejo $\mathrm{k}$ zmanjševanju stopnje stresa na delovnem mestu in tako preprečujejo negativne posledice le-tega na zdravje zaposlenih. Svetovna zdravstvena organizacija v priporočilih za preprečevanje samomorilnega vedenja $\mathrm{v}$ delovnem okolju navaja nekatere splošne predloge za delodajalce, npr. vzpostavitev podpornega in spoštljivega delovnega okolja, aktivno in konstruktivno soočanje $s$ konflikti, razvoj in implementacija učinkovitih aktivnosti na področju duševnega zdravja, vzpostavitev načinov zgodnje prepoznave stresa na delovnem mestu in drugih psihosocialnih dejavnikov tveganja ter svetovalnih služb za posameznike v stiski (npr. zaradi prekinitve delovnega razmerja ali travmatičnih dogodkov v službi), izobraževanje vodstvenih delavcev za prepoznavo psihosocialnih dejavnikov tveganja med zaposlenimi, destigmatizacija iskanja pomoči $\mathrm{V}$ primeru težav $\mathrm{V}$ duševnem zdravju itd. (WHO, 2006). V priporočilih Svetovne zdravstvene organizacije prepoznamo različne ravni aktivnosti za preprečevanje samomora - predvsem pa se poleg vzdrževanja spodbudnih delovnih pogojev osredotočajo na zgoraj omenjeni ravni (ii) dela z ranljivimi skupinami ter (iii) izobraževanja vratarjev sistema vodstvenih delavcev, za prepoznavo potrebe po pomoči pri zaposlenih.

V kontekstu dela $\mathrm{z}$ ranljivimi skupinami bi lahko kot pomembno aktivnost na področju duševnega zdravja izpostavili izobraževanje oz. učenje uspešnega soočanja s stresom in preprečevanje izgorelosti ter krepitev duševnega zdravja. Tovrstna izobraževanja bi lahko vključevala npr. izvajanje na čuječnosti temelječe kognitivne terapije, ki se 
je izkazala za učinkovito pri naslavljanju različnih težav v duševnem zdravju in se kaže kot zelo obetavna tudi za posameznike s samomorilno ideacijo (Luoma in Villatte, 2012). Program se izvaja v majhnih skupinah in vključuje prakticiranje različnih tehnik meditacije in osredotočanja na sedanji trenutek ter določene elemente kognitivnovedenjske terapije (Segal, Williams in Teasdale, 2013). Kot že omenjeno, je poleg tega pomembno zagotavljati dostopnost pomoči za zaposlene, ki se soočajo s hudo stisko ali težavami v duševnem zdravju, pri čemer pa je potrebno razmisliti tudi o razlogih, zakaj zaposleni ne poiščejo pomoči, ko se znajdejo v stiski (Fridner, Belkić, Marini, Sendén in Schenck-Gustafsson, 2012), torej nasloviti morebitne ovire pri iskanju pomoči, med drugim $\mathrm{z}$ aktivnim delovanjem $\mathrm{v}$ smeri destigmatizacije težav $\mathrm{v}$ duševnem zdravju (WHO, 2006).

V praksi se kaže, da je največ preventivnih aktivnosti namenjenih zniževanju tveganja ter zagotavljanju pomoči, ko je ta najbolj potrebna. Navadno vključujejo izobraževanje zaposlenih o duševnem zdravju, prepoznavanje posameznikov s povišanim tveganjem, razvoj podporne mreže med zaposlenimi, sodelovanje $z$ zdravstveni delavci znotraj inštitucije in/ali izven nje ter izobraževanje vodstva in osebja. Te strategije se kažejo kot ustrezne za celosten program preprečevanja samomora in so vsekakor pomembne (Takada in Shima, 2010), vendar je njihova pomanjkljivost, da ne naslavljajo dejavnikov na primarni ravni, torej dejavnikov tveganja v delovnem okolju, ki bi se jih dalo spreminjati - dejavnikov stresa na delovnem mestu. Videti je torej, da se kljub priporočilu Svetovne zdravstvene organizacije preventivne dejavnosti $\mathrm{v}$ premajhni meri osredotočajo na vzpostavljanje in vzdrževanje spodbudnih delovnih pogojev za zaposlene (Milner, Page, Spencer-Thomas in LaMotagne, 2014), kar pa bi bilo še toliko bolj pomembno $\mathrm{v}$ času gospodarske krize. Ob izvedbi preventivnih programov v delovnem okolju je njihova učinkovitost pogosto premalo raziskana (Takada in Shima, 2010) ali pa so programi evalvirani na podlagi opazovanja ali kvazieksperimentalnih načrtov, ki ne omogočajo dovolj zanesljivih zaključkov o njihovi učinkovitosti (Milner, Page idr., 2014).

Glede na vlogo, ki jo ima dostop do sredstev za samomor $\mathrm{v}$ nekaterih poklicih, avtorji opozarjajo tudi na pomen četrte ravni preventivnih aktivnosti, torej preprečevanja oz. omejevanja dostopa do sredstev za samomor (Mustard idr., 2010; Zamorski, 2011). Tovrstne preventivne dejavnosti so relativno enostavno izvedljive in imajo pomembno vlogo pri preprečevanju samomora, tako $\mathrm{v}$ kontekstu zaposlitvenih dejavnikov tveganja (poleg medicinskih poklicev in poklicev, ki omogočajo dostop do strelnega orožja, se je kot učinkovito izkazalo npr. preprečevanje dostopa do pesticidov s pomočjo zaklenjenih omaric pri agrikulturnih delavcih v azijskih državah, kjer se razmeroma veliko samomorov zgodi na ta način), kot tudi sicer (npr. omejevanje dostopa do strelnega orožja, pakiranje zdravil na recept $\mathrm{v}$ manjših embalažah) (Agerbo idr., 2007; Daigle, 2005; Hawton, 2007; Vijayakumar idr., 2013). Preprečevanje dostopa do sredstev za samomor ne odstrani vzrokov posameznikove stiske, lahko pa prepreči impulzivno odločitev za samomor $\mathrm{v}$ trenutku akutne stiske in odpre možnosti za nadaljnje klinične intervencije (Daigle, 2005). Kljub temu se študije večinoma ne ukvarjajo $\mathrm{z}$ vprašanjem omejevanja dostopa do sredstev za samomor med zaposlenimi (Milner, Page idr., 2014), zato lahko o učinkovitosti tovrstnih ukrepov sklepamo le posredno, npr. na podlagi omenjenih spoznanj o tem, da se količniki samomora pri zaposlenih v poklicih z dostopom do sredstev za samomor nižajo (Roberts idr., 2013).

\section{Zaključki}

Številne raziskave se ukvarjajo s pomenom brezposelnosti in potrjujejo njeno povezanost $s$ samomorilnim vedenjem. Prav tako se v študijah potrjuje povezanost neugodnih gospodarskih razmer in visoke stopnje brezposelnosti z večjimi količniki samomora. Pri tem je sama napovedna vrednost brezposelnosti za samomorilno vedenje odvisna od aktualnih razmer na trgu dela, saj je v obdobjih nizke stopnje brezposelnosti močnejša kot $\mathrm{v}$ obdobjih visoke stopnje brezposelnosti. $\mathrm{V}$ času ekonomske recesije je torej potrebno preventivne aktivnosti izvajati za brezposelne (npr. investiranje v trg dela, aktivno spodbujanje odpiranja novih možnosti zaposlovanja), obenem pa tudi za zaposlene, ki se soočajo $z$ različnimi posledicami krize. S samomorilnim vedenjem so namreč povezani neugodni psihosocialni delovni pogoji, pa tudi pogosto menjanje služb, dolgi delovniki, težko delo in skrbi glede stabilnosti zaposlitve. Omenjena spoznanja kažejo na pomen ustvarjanja oz. vzdrževanja ugodnih delovnih pogojev, ki bi imeli v tem kontekstu funkcijo varovalnih dejavnikov. $\mathrm{Na}$ pomen spodbudnih delovnih pogojev opozarja tudi Svetovna zdravstvena organizacija (WHO, 2006), v praksi pa se preventivni programi premalo osredotočajo nanje. Tudi skrbi glede stabilnosti zaposlitve, ki se v povečanem obsegu pojavljajo $\mathrm{v}$ času ekonomske recesije, predstavljajo dejavnik tveganja za samomorilno vedenje. Omenjeni vidiki dela so v veliki meri povezani $\mathrm{z}$ razmerami na trgu dela in zmožnostmi delodajalcev, zato jih je v preventivnih programih težje naslavljati, saj poleg ozaveščanja delodajalcev terjajo ukrepe na širši ravni gospodarstva.

Poleg ukrepov za zmanjševanje posledic recesije zahteva učinkovit pristop k preprečevanju samomorilnega vedenja izvajanje preventivnih dejavnosti na različnih ravneh: od preprečevanja oz. omejevanja dostopa do sredstev za samomor, do specifičnih intervencij, vezanih na konkretne dejavnike tveganja, in varovalne dejavnike pri posameznih poklicih. Pri tem se kaže potreba po boljšem poznavanju teh dejavnikov, za kar bi potrebovali nadaljnje študije v našem kulturnem okolju. Za razvoj kakovostnih preventivnih aktivnosti za skupine ljudi, pri katerih zaradi različnih razlogov (npr. brezposelnost, ogrožene poklicne skupine) obstaja povišano tveganje za samomor, bi bilo predvsem zelo koristno boljše razumevanje varovalnih dejavnikov, ki ščitijo pred samomorilnim vedenjem. 


\section{Literatura}

Agerbo, E. (2005). Effect of psychiatric illness and labour market status on suicide: A healthy worker effect? Journal of Epidemiology and Community Health, 59(7), 598-602.

Agerbo, E., Gunnell, D., Bonde, J. P., Mortensen, P. B. in Nordentoft, M. (2007). Suicide and occupation: The impact of socio-economic, demographic and psychiatric differences. Psychological Medicine, 37, 1131-1140.

Almasi, K., Belso, N., Kapur, N., Webb, R., Cooper, J., Hadley, S., ... Appleby, L. (2009). Risk factors for suicide in Hungary: A case-control study. BMC Psychiatry, 9(1), 1.

Amagasa, T., Nakayama, T. in Takahashi, Y. (2005). Karojisatsu in Japan: Characteristics of 22 cases of work-related suicide. Journal of Occupational Health, 47(2), 157-164.

Barr, B., Taylor-Robinson, D., Scott-Samuel, A., McKee, M. in Stuckler, D. (2012). Suicides associated with the 2008-10 economic recession in England: time trend analysis. $B M J, 345$, e5142.

Beautrais, A. L., Joyce, P. R. in Mulder, R. T. (1998). Unemployment and serious suicide attempts. Psychological Medicine, 28(1), 209-218.

Blakely, T. A., Collings, S. C. D. in Atkinson, J. (2003). Unemployment and suicide. Evidence for a causal association? Journal of Epidemiology and Community Health, 57(8), 594-600.

Braquehais, M. D., Eiroa-Orosa, F. J., Holmes, K. M., Lusilla, P., Bravo, M., Mozo, X., ... Sher, L. (2014). Differences in Physicians' and Nurses' Recent Suicide Attempts: An Exploratory Study. Archives of Suicide Research. doi:10.1080/13811118.2014.996693

Chang, S.-S., Stuckler, D., Yip, P. in Gunnell, D. (2013). Impact of 2008 global economic crisis on suicide: Time trend study in 54 countries. BMJ, 347, f5239.

Classen, T. J. in Dunn, R. A. (2012). The effect of job loss and unemployment duration on suicide risk in the United States: A new look using mass-layoffs and unemployment duration. Health Economics, 21(3), 338-350.

Corcoran, P. in Arensman, E. (2010). Suicide and employment status during Ireland's Celtic Tiger economy. European Journal of Public Health, 21(2), 209-214.

Crawford, M. J., Kuforiji, B. in Ghosh, P. (2010). The impact of social context on socio-demographic risk factors for suicide: a synthesis of data from case-control studies. Journal of Epidemiology and Community Health, 64(6), 530-534.

Crump, C., Sundquist, K., Sundquist, J. in Winkleby, M. A. (2014). Sociodemographic, psychiatric and somatic risk factors for suicide: A Swedish national cohort study. Psychological Medicine, 44(2), 279-89.

Daigle, M. S. (2005). Suicide prevention through means restriction. Accident Analysis and Prevention, 37, $625-632$.
Feskanich, D., Hastrup, J. L., Marshall, J. R., Colditz, G. A, Stampfer, M. J., Willett, W. C. in Kawachi, I. (2002). Stress and suicide in the Nurses' Health Study. Journal of Epidemiology and Community Health, 56(2), 95-98.

Fink-Miller, E. L. (2015). Provocative work experiences predict the acquired capability for suicide in physicians. Psychiatry Research, 20. doi: 10.1016/j.psychres.2015.07.055.

Fridner, A., Belkić, K., Marini, M., Sendén, M. G. in Schenck-Gustafsson, K. (2012). Why don't academic physicians seek needed professional help for psychological distress? Swiss Medical Weekly, 142, doi: 10.4414/smw.2012.13626.

Fridner, A., Belkić, K., Minucci, D., Pavan, L., Marini, M., Pingel, B., ... Schenck-Gustafsson, K. (2011). Work environment and recent suicidal thoughts among male university hospital physicians in Sweden and Italy: The Health and Organization among University Hospital Physicians in Europe (HOUPE) study. Gender Medicine, 8, 269-279.

Gold, K. J., Sen, A. in Schwenk, T. L. (2013). Details on suicide among US physicians: Data from the National Violent Death Reporting System. General Hospital Psychiatry, 35(1), 45-49.

Goldman-Mellor, S. J., Saxton, K. B. in Catalano, R. C. (2010). Economic contraction and mental health. International Journal of Mental Health, 39(2), 6-31.

Haw, C., Hawton, K., Gunnell, D. in Platt, S. (2015). Economic recession and suicidal behaviour: Possible mechanisms and ameliorating factors. The International Journal of Social Psychiatry, 61(1), $73-81$.

Hawton, K. (2007). Restricting access to methods of suicide: Rationale and evaluation of this approach to suicide prevention. Crisis, 28(Suppl. 1), 4-9.

Hawton, K., Agerbo, E., Simkin, S., Platt, B. in Mellanby, R. J. (2011). Risk of suicide in medical and related occupational groups: A national study based on Danish case population-based registers. Journal of Affective Disorders, 134(1-3), 320-326.

Kolves, K. in De Leo, D. (2013). Suicide in medical doctors and nurses: An analysis of the Queensland suicide register. Journal of Nervous and Mental Disease, 201, 987-990.

Korošec Jagodič, H., Rokavec, T., Agius, M. in Pregelj, P. (2013). Availability of mental health service providers and suicide rates in Slovenia: a nationwide ecological study. Brain and Mental Health, 54, 444-452.

Kposowa, A. J. (2001). Unemployment and suicide: A cohort analysis of social factors predicting suicide in the US National Longitudinal Mortality Study. Psychological Medicine, 31(1), 127-138.

Laanani, M., Ghosn, W., Jougla, E. in Rey, G. (2014). Impact of unemployment variations on suicide mortality in Western European countries (2000-2010). Journal of Epidemiology and Community Health, 69, 103-109. 
Legleye, S., Beck, F., Peretti-Watel, P., Chau, N. in Firdion, J. M. (2010). Suicidal ideation among young French adults: Association with occupation, family, sexual activity, personal background and drug use. Journal of Affective Disorders, 123(1-3), 108-115.

Lindfors, P. M., Meretoja, O. A., Luukkonen, R. A., Elovainio, M. J.inLeino, T. J.(2009). Suicidality among Finnish anaesthesiologists. Acta Anaesthesiologica Scandinavica, 53(8), 1027-1035.

Luoma, J. B. in Villatte, J. L. (2012). Mindfulness in the treatment of suicidal individuals. Cognitive Behavioural Practice, 19(2), 265-276.

Makinen, I. H. (1999). Effect on suicide rate of having reduced unemployment is uncertain. BMJ, 318, 941-942.

Makinen, I. H. in Wasserman, D. (2009). Labour market, work environment and suicide. V D. Wasserman in C. Wasserman (ur.), Oxford Textbook of Suicidology and Suicide Prevention (str. 221-228). New York: Oxford University Press.

Mann, J. J., Haas, A., Mehlum, L. in Phillips, M. (2005). Suicide Prevention Strategies. JAMA, 294(16), 2064-2074.

Mann, J. J., Waternaux, C., Haas, G. L. L. in Malone, K. M. M. (1999). Toward a clinical model of suicidal behavior in psychiatric patients. The American Journal of Psychiatry, 156(2), 181-189.

Milner, A., Morrell, S. in LaMontagne, A. D. (2014). Economically inactive, unemployed and employed suicides in Australia by age and sex over a 10-year period: What was the impact of the 2007 economic recession? International Journal of Epidemiology, 43(5), 1-8.

Milner, A., Page, A. in LaMontagne, A. D. (2013). Longterm unemployment and suicide: A systematic review and meta-analysis. Plos One, 8(1), 1-6.

Milner, A., Page, K., Spencer-Thomas, S. in LaMotagne, A. D. (2014). Workplace suicide prevention: A systematic review of published and unpublished activities. Health Promotion International, 30(1), 29-37.

Milner, A., Spittal, M. J., Pirkis, J. in LaMontagne, A. D. (2013). Suicide by occupation: Systematic review and meta-analysis. British Journal of Psychiatry, 203, 409-416.

Mishara, B. L. in Martin, N. (2012). Effects of a comprehensive police suicide prevention program. Crisis, 33(3), 162-168.

Mustard, C. A., Bielecky, A., Etches, J., Wilkins, R., Tjepkema, M., Amick, B. C., ... Aronson, K. J. (2010). Suicide mortality by occupation in Canada, 1991-2001. Canadian Journal of Psychiatry, 55(6), 369-376.

Nacionalni inštitut za zdravje (NIJZ). (2015). Zaradi samomora je lani v Sloveniji umrlo 388 ljudi [388 people died due to suicide last year in Slovenia]. Pridobljeno s spletne strani http://www.nijz.si/zaradisamomora-je-lani-v-sloveniji-umrlo-388-ljudi
Norström, T. in Grönqvist, H. (2015). The Great Recession, unemployment and suicide. Journal of Epidemiology and Community Health, 69(2), 110-116.

O'Connor, R. C. (2011). Towards an integrated motivational-volitional model of suicidal behaviour. V R. C. O'Connor, S. Platt in J. Gordon (ur.), International handbook of suicide prevention (str. 181-198). Chichester, Združeno kraljestvo: John Wiley \& Sons.

O’Connor, R. C. in Nock, M. K. (2014). The psychology of suicidal behaviour. The Lancet Psychiatry, 1, 73-85.

Ostry, A., Maggi, S., Tansey, J., Dunn, J., Hershler, R., Chen, L., ... Hertzman, C. (2007). The impact of psychosocial work conditions on attempted and completed suicide among western Canadian sawmill workers. Scandinavian Journal of Public Health, 35, 265-271.

Petersen, M. R. in Burnett, C. A. (2008). The suicide mortality of working physicians and dentists. Occupational Medicine, 58(1), 25-29.

Platt, B., Hawton, K., Simkin, S. in Mellanby, R. J. (2012). Suicidal behaviour and psychosocial problems in veterinary surgeons: A systematic review. Social Psychiatry and Psychiatric Epidemiology, 47, 223-240.

Platt, S. (2011). Inequalities and suicidal behaviour. V R. C. O'Connor, S. Platt in J. Gordon (ur.), International handbook of suicide prevention (str. 211-234). Chichester, Združeno kraljestvo: John Wiley \& Sons.

Pompili, M., Innamorati, M., Di Vittorio, C., Baratta, S., Masotti, V., Badaracco, A., ... Amore, M. (2014). Unemployment as a risk factor for completed suicide: A psychological autopsy study. Archives of Suicide Research, 18, 181-192.

Rihmer, Z. (2011). Depression and suicidal behaviour. V R. C. O'Connor, S. Platt in J. Gordon (ur.), International handbook of suicide prevention (str. 59-73). Chichester, Združeno kraljestvo: John Wiley \& Sons.

Roberts, S. E., Jaremin, B. in Lloyd, K. (2013). High-risk occupations for suicide. Psychological Medicine, 43, 1231-1240.

Rosta, J. in Aasland, O. G. (2013). Changes in the lifetime prevalence of suicidal feelings and thoughts among Norwegian doctors from 2000 to 2010: A longitudinal study based on national samples. BMC Psychiatry, $13,1-10$.

Roškar, S. (2009). Senca na sončni strani Alp [Shadow on the sunny side of the Alps]. V A. Tančič, V. Poštuvan in S. Roškar (ur.), Spregovorimo o samomoru med mladimi [Let's talk about suicide among youth] (str. 19-21). Ljubljana: Inštitut za varovanje zdravja.

Schernhammer, E. S. in Colditz, G. A. (2004). Suicide rates among physicians: A quantitative and gender assessment (meta-analysis). American Journal of Psychiatry, 161, 2295-2302. 
Schneider, B., Grebner, K., Schnabel, A., Hampel, H., Georgi, K. in Seidler, A. (2011). Impact of employment status and work-related factors on risk of completed suicide: A case-control psychological autopsy study. Psychiatry Research, 190(2-3), 265-270.

Segal, Z. V, Williams, J. M. G. in Teasdale, J. D. (2013). Mindfulness-based cognitive therapy for depression (2. izd.). New York, NY, ZDA: The Guilford Press.

Skegg, K., Firth, H., Gray, A. in Cox, B. (2010). Suicide by occupation: Does access to means increase the risk? The Australian and New Zealand Journal of Psychiatry, 44, 429-434.

Stuckler, D., Basu, S., Suhrcke, M., Coutts, A. in McKee, M. (2009). The public health effect of economic crises and alternative policy responses in Europe: An empirical analysis. The Lancet, 374, 315-323.

Takada, M. in Shima, S. (2010). Characteristics and effects of suicide prevention programs: Comparison between workplace and other settings. Industrial Health, 48, 416-426.

Tsutsumi, A., Kayaba, K., Ojima, T., Ishikawa, S., Kawakami, N., Hashimoto, A., .. Nakamura, Y. (2007). Low control at work and the risk of suicide in Japanese men: A prospective cohort study. Psychotherapy and Psychosomatics, 76(3), 177-185.

Van der Feltz-Cornelis, C. M., Sarchiapone, M., Poštuvan, V., Volker, D., Roškar, S., Grum, A. T., ... Hegerl, U. (2011). Best practice elements of multilevel suicide prevention strategies: A review of systematic reviews. Crisis, 32, 319-333.

Van Orden, K. A., Witte, T. K., Cukrowicz, K. C., Braithwaite, S., Selby, E. A. in Joiner, T. E. (2010). The Interpersonal Theory of Suicide. Psychological Review, 117(2), 575-600.

Vanderoost, F., Van Der Wielen, S., Van Nunen, K. in Van Hal, G. (2013). Employment loss during economic crisis and suicidal thoughts in Belgium: A survey in general practice. British Journal of General Practice, 63, 691-697.

Vijayakumar, L., Jeyaseelan, L., Kumar, S., Mohanraj, R., Devika, S. in Manikandan, S. (2013). A central storage facility to reduce pesticide suicides--a feasibility study from India. BMC Public Health, 13, doi: 10.1186/1471-2458-13-850

Williams, J. M. G. in Pollock, L. R. (2001). Psychological aspects of the suicidal process. V K. Van Heeringen (ur.), Understanding suicidal behaviour: The suicidal process approach to research, treatment and prevention (str. 76-93). Chichester, Združeno kraljestvo: John Wiley \& Sons.

Windfuhr,K.in Kapur, N.(2011). International perspectives on the epidemiology and aetiology of suicide and selfharm. V R. C. O'Connor, S. Platt in J. Gordon (ur.), International handbook of suicide prevention (str. 27-58). Chichester, Združeno kraljestvo: John Wiley $\&$ Sons.

Wolfersdorf, M. (2007). Suicide and suicide prevention for female and male physicians. MMW Fortschritte der Medizin, 28(149), 34-36.
World Health Organization (WHO). (2006). Preventing suicide: A resource at work. Geneva, Switzerland: WHO.

World Health Organization (WHO). (2014). European mortality database. Pridobljeno s spletne strani http:// data.euro.who.int/hfamdb/

Ying, Y.-H. in Chang, K. (2009). A study of suicide and socioeconomic factors. Suicide \& Life-Threatening Behavior, 39(2), 214-226.

Yip, P. S. F. in Caine, E. D. (2011). Employment status and suicide: The complex relationships between changing unemployment rates and death rates. Journal of Epidemiology and Community Health, 65(8), 733-736.

Yur'yev, A., Värnik, A., Värnik, P., Sisask, M. in Leppik, L. (2012). Employment status influences suicide mortality in Europe. International Journal of Social Psychiatry, 58(1), 62-68.

Zamorski, M. A. (2011). Suicide prevention in military organizations. International Review of Psychiatry, 23, 173-180. 